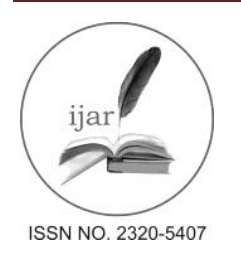

\author{
Journal homepage: http://www.journalijar.com \\ Journal DOI: 10.21474/IJAR01
}

INTERNATIONAL JOURNAL

OF ADVANCED RESEARCH

RESEARCH ARTICLE

\title{
STRUCTURAL, SPECTRAL, DFT, ION-FLOTATION AND BIOLOGICAL STUDIES ON TRANSITION METAL COMPLEXES OF 2-AMINOTHIAZOLE DERIVATIVES.
}

\author{
"Rania Zaky, Ahmed Fekri, Yasmeen G. Abou El-Reash, Hany M. Youssef, Abdulrahman Y. Kareem. \\ Department of Chemistry, Faculty of Science, Mansoura University, Mansoura, Egypt.
}

\section{Manuscript Info}

Manuscript History:

Received: 14 April 2016

Final Accepted: 19 May 2016

Published Online: June 2016

Key words:

Hydrazone complexes,

Spectroscopy, DFT, Ion-flotation,

Cytotoxic, Anti-oxidant..

*Corresponding Author

Rania Zaky.

\section{Abstract}

A series of $\mathrm{Ni}(\mathrm{II}), \mathrm{Zn}(\mathrm{II}), \mathrm{Cu}(\mathrm{II})$ and $\mathrm{Fe}(\mathrm{III})$ complexes of the 3-(2-(4(dimethylamino)benzylidene)hydrazinyl)-3-oxo-N-(thiazol-2-

yl)propanamide $\left(\mathrm{H}_{2} \mathrm{~L}\right)$ were synthesized. The produced compounds were illustrated by different spectroscopic techniques.The geometry of the produced compounds was predicated by computational studying via DFT method.Furthermore, the flotation method was used to separate $\mathrm{Zn}(\mathrm{II})$ and $\mathrm{Cu}(\mathrm{II})$ ions. In addition, the antimicrobial, anti-oxidant and cytotoxic of the prepared compounds were tested.

Copy Right, IJAR, 2016,. All rights reserved.

\section{Introduction:-}

Hydrazone complexes derived from heterocyclic compounds containing oxygen, nitrogen and/or sulfur as donor atoms are attention models for biological systems [1-3]. Heterocycles, especially thiazoles, occupy an important place owing to their versatile bioactivities due to the presence of multifunctional groups $[4,7]$.Transition metal complexeshaveanenergetic role in a numerous of biological systems. The chemical compounds that containing 2aminothiazole moiety have significant role in pharmaceutical chemistry because it used in the improvement of drugs as anti-HIV agent, anti-inflammatory, anti-hypertensive, cytotoxic, anti-oxidant, cardiotonic and anti-allergies. Still, these compounds were interested in organic as well as inorganic chemistry due to their wide applications in medicine.

Also, hydrazone derivatives were used as selective metal extracting agents in analytical chemistry in addition to the determination of certain transition metals in the spectroscopy [6-10]. A lot of preconcentration/separation methods (ion-flotation, column extraction, ion-selective electrode, cloud point extraction, liquid-liquid extraction, solid phase extraction and co-precipitation) were used to determine trace metal.In the current article we will apply ion-flotation techniquesince it was a fast, simple and economical technique for metal analysis to overcome the problems attended with the use of highly classy apparatuses [11-14].

In addition of our work on hydrazone of 2-amino thiazoles derivatives [15-19], the present work aimed to the production and characterizationof $\mathrm{Ni}(\mathrm{II}), \mathrm{Fe}(\mathrm{III}), \mathrm{Zn}(\mathrm{II})$ and $\mathrm{Cu}(\mathrm{II})$ complexes. The mode of chelation was elucidated by means of numerousof spectroscopic methods. Also, the cytotoxic, anti-oxidant and antimicrobial of the prepared compounds were tested.

\section{Experimental:-}

Materials and reagents:-

The chemicals used were pure (Merck, Aldrich or Sigma). They included: 
a. Organic substance as; oleic acid (HOL), 4-dimethylamino-benzaldehyde and 3-hydrazinyl-oxo-N-(thiazole-2)propanamide

b. Metal salts as; $\mathrm{NiCl}_{2} \cdot 6 \mathrm{H}_{2} \mathrm{O}, \mathrm{CuCl}_{2} \cdot 2 \mathrm{H}_{2} \mathrm{O}, \mathrm{ZnCl}_{2}$ and $\mathrm{FeCl}_{3}$

c. Solvent as; absolute ethanol, diethyl ether and dimethyl formamide.

\section{Solutions:-}

A stock solution of HOL $\left(6.36 \times 10^{-2} \mathrm{~mol} . \mathrm{L}^{-1}\right)$ was prepared by adding $20 \mathrm{~mL}$ in one liter of kerosene. Similarly, stock solutions of $\mathrm{ZnCl}_{2}$ and $\mathrm{CuCl}_{2} \cdot 2 \mathrm{H}_{2} \mathrm{O}\left(1 \times 10^{-2}\right.$ mol. $\left.\mathrm{L}^{-1}\right)$ were prepared in bidistilled water. Also, stock solution of $1 \times 10^{-2}$ mol. $\mathrm{L}^{-1}$ of $\mathrm{H}_{2} \mathrm{~L}$ was prepared in absolute ethanol.

\section{Instrumentation:-}

* The infrared spectra were detected by using FTIR spectrophotometer Mattson 5000, Madison, USAin the range $4,000-400 \mathrm{~cm}^{-1}$.

* The ${ }^{1} \mathrm{H}$ NMR spectra were detected by using EM-390 (200 MHz) on a Varian Mercury-300 instrument (Switzerland).

* The MS spectra were determined by using Mattson 5000 FTIR spectrophotometer.

* The values of magnetic moment were estimated at room temperature $\left(25 \pm 1^{\circ} \mathrm{C}\right)$ by using magnetic susceptibility balance "Johnson Matthey Wayne, Pennsylvania, USA".

* The electronic spectra was recorded in DMSO by using "Shimadzu UV 240 (P/N 204-58000) spectrophotometer (USA) in the range 200-900 nm"

* The GBC, Sensaa Series Atomic Absorption Spectrometry (computerized AAS) with air-acetylene flame was used to determine the analyte concentration.

* Two types of cells were used in the flotation and separation experiments. Which are cylindrical tube of (29, 45) $\mathrm{cm}$ length and $(1.2,6) \mathrm{cm}$ inner diameter with a stopper at the top was used to training the various factors affecting the separation of the tested ions from aqueous solutions.

* The pH values were determined by using Hanna instrument 8519 digital pH meter.

* The percentage of $\mathrm{C}, \mathrm{H}$ and $\mathrm{N}$ were determined by using Perkin-Elmer 2400 Series II Analyzer (Table 1).

* The standard methods used to determine the metal contents in the complexes [20].

Table 1: Analytical and Physical Data of $\mathrm{H}_{2} \mathrm{~L}$ and Its Metal Complexes.

\begin{tabular}{|c|c|c|c|c|c|c|c|c|c|c|}
\hline $\mathrm{N}$ & \multirow[t]{2}{*}{ Compound } & \multirow{2}{*}{$\begin{array}{l}\text { Empirical } \\
\text { formula } \\
\text { (molecular } \\
\text { mass) }\end{array}$} & \multirow[t]{2}{*}{ Color } & \multirow{2}{*}{$\begin{array}{l}\text { M.P } \\
\left({ }^{\circ} \mathrm{C}\right)\end{array}$} & \multirow{2}{*}{$\begin{array}{c}\text { Yield } \\
\%\end{array}$} & \multicolumn{5}{|c|}{$\%$ Found (calculated) } \\
\hline & & & & & & $\mathrm{C}$ & $\mathrm{H}$ & $\mathrm{N}$ & $\mathrm{M}$ & $\mathrm{Cl}$ \\
\hline 1 & $\mathrm{H}_{2} \mathrm{~L}$ & $\begin{array}{c}\mathrm{C}_{15} \mathrm{H}_{17} \mathrm{O}_{2} \mathrm{~N}_{5} \mathrm{~S} \\
(331.353)\end{array}$ & $\begin{array}{c}\text { pale } \\
\text { yellow }\end{array}$ & 192 & 80 & $\begin{array}{c}54.17 \\
(54.3 \\
7)\end{array}$ & $\begin{array}{c}4.99 \\
(5.17)\end{array}$ & $\begin{array}{c}21.17 \\
(21.1 \\
4)\end{array}$ & - & - \\
\hline 2 & $\begin{array}{c}{\left[\mathrm{Ni}\left(\mathrm{H}_{2} \mathrm{~L}\right)\left(\mathrm{H}_{2} \mathrm{O}\right) \mathrm{Cl}_{2}\right] \cdot 2 \mathrm{H}} \\
{ }_{2} \mathrm{O}\end{array}$ & $\begin{array}{c}\mathrm{Ni} \mathrm{C}_{15} \mathrm{H}_{23} \mathrm{O}_{5} \mathrm{~N}_{5} \mathrm{~S} \\
\mathrm{Cl}_{2} \\
(515.080)\end{array}$ & brown & $\begin{array}{c}> \\
250\end{array}$ & 60 & $\begin{array}{c}34.86 \\
(34.9 \\
8)\end{array}$ & $\begin{array}{c}4.49 \\
(4.50)\end{array}$ & $\begin{array}{c}13.58 \\
(13.6 \\
0)\end{array}$ & $\begin{array}{c}11.36 \\
(11.3 \\
9)\end{array}$ & $\begin{array}{c}13.72 \\
(13.7 \\
8)\end{array}$ \\
\hline 3 & {$\left[\mathrm{Fe}\left(\mathrm{H}_{2} \mathrm{~L}\right) \mathrm{Cl}_{3}\right] \cdot 2 \mathrm{H}_{2} \mathrm{O}$} & $\begin{array}{c}\mathrm{Fe} \mathrm{C}_{15} \mathrm{H}_{21} \mathrm{O}_{4} \mathrm{~N}_{5} \mathrm{~S} \\
\mathrm{Cl}_{3} \\
(529.733)\end{array}$ & $\begin{array}{l}\text { yellowis } \\
\text { h white }\end{array}$ & $\begin{array}{c}> \\
250\end{array}$ & 50 & $\begin{array}{c}34.15 \\
(34.0 \\
1)\end{array}$ & $\begin{array}{c}3.86 \\
(3.99)\end{array}$ & $\begin{array}{c}13.01 \\
(13.2 \\
2)\end{array}$ & $\begin{array}{c}10.50 \\
(10.5 \\
4)\end{array}$ & $\begin{array}{c}20.14 \\
(20.1 \\
9)\end{array}$ \\
\hline 4 & {$\left[\mathrm{Zn}(\mathrm{HL})_{2}\right]$} & $\begin{array}{c}\mathrm{Zn} \\
\mathrm{C}_{30} \mathrm{H}_{32} \mathrm{O}_{4} \mathrm{~N}_{10} \mathrm{~S}_{2} \\
(690.04)\end{array}$ & $\begin{array}{l}\text { yellowis } \\
\text { h white }\end{array}$ & $\begin{array}{c}> \\
250\end{array}$ & 70 & $\begin{array}{c}52.34 \\
(52.2 \\
2)\end{array}$ & $\begin{array}{c}4.72 \\
(4.67)\end{array}$ & $\begin{array}{c}20.19 \\
(20.3 \\
0)\end{array}$ & $\begin{array}{l}9.50 \\
(9.47)\end{array}$ & - \\
\hline 5 & {$\left[\mathrm{CuL}\left(\mathrm{H}_{2} \mathrm{O}\right)\right] \cdot 2 \mathrm{H}_{2} \mathrm{O}$} & $\begin{array}{c}\mathrm{Cu} \\
\mathrm{C}_{15} \mathrm{H}_{21} \mathrm{O}_{5} \mathrm{~N}_{5} \mathrm{~S} \\
(446.930)\end{array}$ & brown & $\begin{array}{c}> \\
250\end{array}$ & 60 & $\begin{array}{c}40.02 \\
(46.3 \\
1)\end{array}$ & $\begin{array}{c}4.31 \\
(4.74)\end{array}$ & $\begin{array}{c}15.58 \\
(15.6 \\
7)\end{array}$ & $\begin{array}{c}14.18 \\
(14.2 \\
2)\end{array}$ & - \\
\hline
\end{tabular}

\section{Synthesis of $\mathrm{H}_{2} \mathrm{~L}$ :-}

The ligand was synthesized by adding equimolar quantities of 4-Dimethylamino-benzaldehyde ( $0.01 \mathrm{~mol} ; 1.5 \mathrm{~g})$ and 3-hydrazinyl-oxo-N-(thiazole-2-)propanamide $(0.01 \mathrm{~mol} ; 2 \mathrm{~g})$ in $50 \mathrm{ml}$ absolute ethyl alcohol in presences of $1 \mathrm{ml}$ glacial acetic acid. The $\mathrm{H}_{2} \mathrm{~L}$ was produced through reflux $(3 \mathrm{hrs})$ and then separated by filtration followed by recrystallization from ethanol. 


\section{Synthesis of metal complexes:-}

The complexes were produced by reflux equimolar quantities of $\mathrm{H}_{2} \mathrm{~L}(3.31 ; 10.0 \mathrm{mmol})$ and $10.0 \mathrm{mmol}$ of copper (II), nickel (II), zinc (II), and ferric (III) for 1-3 h. The formed precipitate was filtered off, washed with hot ethanol and distilled water (Scheme 1).

\section{Molecular modeling:-}

Scheme 1:- The outline of the synthesis of $\mathrm{H}_{2} \mathrm{~L}$ and its metal complexes

The cluster calculations was evaluate by using DMOL3 program in materials studio package [21, 22]. Thegeometry optimization of the prepared compounds was predicated by using the DFT (density functional theory) through the GAUSSIAN 09 program package. The DNP basis sets are of analogous class to 6-31G Gaussian basis sets [23]. The Gaussian basis sets are less accurate than DNP basis sets of the same size [24]. The PBEPBE functional [25] was considered the best brilliant exchange-correlation functional based on the GGA (generalized gradient approximation) [26].

\section{Biological activity:-}

Antibacterial and antifungal activities:-

* By applying agar streak dilution technique the MIC of the produced compounds was detected [27].

* The strains includedGram positive bacteria (Bacillus subtilis and Staphylococcus aureus), Gram negative bacteria(Pseudomonas aeuroginosa and Escherichia) andpathogenic fungi (Candida albicans and Aspergillus flavus).

* The Fluconazole $(100 \mu \mathrm{g} / \mathrm{ml})$ was used as standard for anti-fungal while Ciprofloxacin $(100 \mu \mathrm{g} / \mathrm{ml})$ used as standard for anti-bacterial.

* A $100 \mu \mathrm{g} / \mathrm{ml}$ stock solution of the tested compounds in DMSO was synthesized and then incorporated in definiteamount ofmolten sterile.

* A definitequantity of the medium inclosinginvestigated compound was poured into a Petri dish until reach 3-4 $\mathrm{mm}$ of depth at $40-50{ }^{\circ} \mathrm{C}$, and then allowable to solidify.

* The micro-organism suspension was established to take about $105 \mathrm{cfu} / \mathrm{ml}$ and muddy to plates with diluted compounds in DMSO to be established and then, incubated at $37^{\circ} \mathrm{C}$ for $24-48 \mathrm{~h}$. 
* The MIC was determinedtill the lowermost concentration of the investigated substance viewing no visible growth of fungi or bacteria on the plate.

Anti-oxidant activity screening assay:-

Anti-oxidant activity screening assay - ABTS method:-

* In ABTS method; $3 \mathrm{ml} \mathrm{MnO} 2(25 \mathrm{mg} / \mathrm{ml})$ solution and $2 \mathrm{ml}$ of ABTS $(60 \mathrm{mM})$ solution was added to tested compounds in presence of $5 \mathrm{ml}$ aqueous phosphate buffer solution ( $\mathrm{pH} 7,0.1 \mathrm{M})$.

* The prepared mix was shaken, centrifuged, filtered.Then the absorbance was recordedfor the ABTS radical solution (resultant green-blue solution) at $\lambda 734 \mathrm{~nm}$.

* After that, $50 \mathrm{ml}$ of methanol/phosphate buffer (1:1) was added to the tested compounds (2 mM)in the spectroscopic grade.

* The absorbance was measured by using L-ascorbic acid (positive control) as antioxidant standard. While, the ABTS and methanol/phosphate buffer (1:1) used as a negative control [28, 29].

* The intensity of color reduction was determined by using the following equation:

$$
\mathrm{I} \%=\left(\mathrm{A}_{\text {blank }}-\mathrm{A}_{\text {sample }}\right) /\left(\mathrm{A}_{\text {blank }}\right) \times 100
$$

Where $A_{\text {blank }}$ is the absorbance of the reaction control,

$\mathrm{A}_{\text {sample }}$ is the absorbance in the existence of the samples or standards.

\section{Anti-oxidant screening assay for erythrocyte hemolysis:-}

* Blood was obtained by cardiac puncture from rats and then collected in heparinized tubes.

* A regularly packed cell of Erythrocytes were prepared from the buffy coat and plasma. Where, it was washed by0.15 M NaCl (three times), and centrifuged for $10 \mathrm{~min}$ at $2500 \mathrm{rpm}$.

* In this test,the erythrocyte hemolysis was mediated by peroxyl radicals [30].

* In order to test the samples at different concentrations, 10\% of erythrocytes suspension atpH 7.4 (PBS) was added to the similar volume of AAPH solution (200 mM)in PBS. Then the reaction mixture was shaken and being incubated at $37^{\circ} \mathrm{C}$ for $1 \mathrm{~h}$.

* Next, the mixture was separated, diluted with 8 volumes of PBS and centrifuged for ten min at $2500 \mathrm{rpm}$. The absorbance (A) of the supernatant was recorded at $540 \mathrm{~nm}$.

* Similarly, the mixture was conserved with 8 volumes of distilled water to reachcomplete hemolysis. Then, after centrifugation the absorbance (B) of the supernatant was determinedat $540 \mathrm{~nm}$. The hemolysis percentage was measured by using this equation:

\section{Cell proliferation assay:-}

$$
\% \text { hemolysis }=(1-\mathrm{A} / \mathrm{B}) \times 100 \%
$$

* The MTT colorimetric assay used to determine the inhibitory effects of the tested compounds on cell growth $[31,32]$.

* The Penicillin (100 units/ml ) and Streptomycin $(100 \mu \mathrm{g} / \mathrm{ml})$ are antibiotics that used under $5 \% \mathrm{CO}_{2}$ for $48 \mathrm{~h}$ incubator at $37^{\circ} \mathrm{C}$ and seeds in a 96-well plate with density $1.0 \times 10^{4}$ cells/well [33, 34].

* After that, the incubated cells were preserved with various concentration of tested compounds for $24 \mathrm{~h}$. following, $24 \mathrm{~h}$ of drug treatment, $20 \mu \mathrm{l}$ of MTT solution at $5 \mathrm{mg} / \mathrm{ml}$ was added and incubated for $4 \mathrm{~h}$.

* Then $100 \mu$ l of DMSO was added to each well to dissolve the purple formazan.

* The colorimetric test was measured by using a plate reader (EXL 800, USA) at $570 \mathrm{~nm}$.

* The relative cell viability percentage was determined by applyingthis equation:

A570 of treated samples/A570 of untreated sample x 100.

\section{Flotation-separation procedure:-}

Aknownquantity of copper (II) or zinc (II) solutions was added to a solution of $\mathrm{H}_{2} \mathrm{~L}$. The pH of the prepared mixture was adjusted with sodium hydroxide and/or nitric acid to the wanted value. After that, the solution was completedwith bidistilled water to $10 \mathrm{~mL}$ in the flotation cell. The cell was shacked well for $2 \mathrm{~min}$ and then $2 \mathrm{~mL}$ of known concentration of HOL were added toconfirm complete complexation. After that, the cell was reversed upside down 20 times and left $5 \mathrm{~min}$ standing for complete flotation. Lastly, the concentration of copper (II) or zinc (II) ions stayed in the mother liquor was analyzed via AAS. The floatability (F \%) of copper (II) or zinc (II) ions was measuredby applying this equation:

$$
\mathrm{F} \%=\left(\mathrm{C}_{\mathrm{i}}-\mathrm{C}_{\mathrm{f}}\right) / \mathrm{Ci} \times 100
$$


Where: $C_{i}$ and $C_{f}$ are the initial and the final concentrations of copper (II) or zinc (II) ions in the mother liquor, respectively.

\section{Results and Discussion:-}

IR, ${ }^{1}$ H NMR and mass spectra:-

The important IR bands $\mathrm{H}_{2} \mathrm{~L}$ and its metal complexes were considered to determine the effect of a metal bonding on the ligand vibration in the produced complexes. The IR spectrum of $\mathrm{H}_{2} \mathrm{Lw}$ as exhibited a medium-intensity broad bands related to $v\left(\mathrm{CH}_{2}\right), v(\mathrm{NH})_{1}$ and $v(\mathrm{NH})_{2}$ at 3089,3200 and $3174 \mathrm{~cm}^{-1}$ [35], respectively. Furthermore, there are three sharp bands related to $v(\mathrm{C}=\mathrm{O})_{1}, \mathrm{v}(\mathrm{C}=\mathrm{O})_{2}[36]$ and $v(\mathrm{C}=\mathrm{N})[37]$ at 1688,1667 and $1605 \mathrm{~cm}^{-1}$, respectively $($ Table 2).

Table 2:- Most important IR spectra bands of $\mathrm{H}_{2} \mathrm{~L}$ and its metal complexes.

\begin{tabular}{|c|c|c|c|c|c|c|c|c|c|c|}
\hline Compound & $v(N H)_{1}$ & $v(N H)_{2}$ & $v\left(\mathrm{CH}_{2}\right)$ & $v(\mathrm{C}=\mathrm{O})_{1}$ & $v(\mathrm{C}=\mathrm{O})_{2}$ & $v(\mathrm{C}=\mathrm{N})$ & $\mathrm{v}(\mathrm{C}=\mathrm{N})_{1}$ & $v(\mathrm{C}=\mathrm{N})_{2}$ & $v(\mathrm{C}=\mathrm{O})_{1(\mathrm{enolic})}$ & $\mathrm{v}(\mathrm{C}=\mathrm{O})_{2(\text { enolic })}$ \\
\hline 1 & 3200 & 3174 & 3089 & 1688 & 1667 & 1605 & - & - & - & - \\
\hline 2 & 3227 & 3187 & 3093 & 1671 & 1656 & 1583 & - & - & - & - \\
\hline 3 & 3385 & 3211 & 3080 & 1668 & 1640 & 1600 & - & - & - & - \\
\hline 4 & 3244 & - & 3084 & 1665 & - & 1590 & - & 1603 & - & 1123 \\
\hline 5 & - & - & 3082 & - & - & 1581 & 1636 & 1610 & 1170 & 1128 \\
\hline
\end{tabular}

In ${ }^{1} \mathrm{H}$ NMR spectrum of $\mathrm{H}_{2} \mathrm{~L}$ there are two signals at 11.27 and $12.23 \mathrm{ppm}$ ascribed to the protons of $(\mathrm{NH})_{1}$ and $(\mathrm{NH})_{2}$, respectively. Also, in 6.60-8.04 ppm region there are multiple signals related to the aromatic protons and $\mathrm{N}=\mathrm{CH}-$. Moreover, there are two sharp singlet at 3.46 and $3.79 \mathrm{ppm}$ associated to the protons of $\left(-\mathrm{C} \underline{\mathrm{H}}_{2}\right)$ and ph- $-\mathrm{N}-$ $\left(\mathrm{CH}_{3}\right)_{2}$, respectively. (Figure1)<smiles>CN(C)c1ccc(/C=N/NC(=O)CC(=O)Nc2nccs2)cc1</smiles>

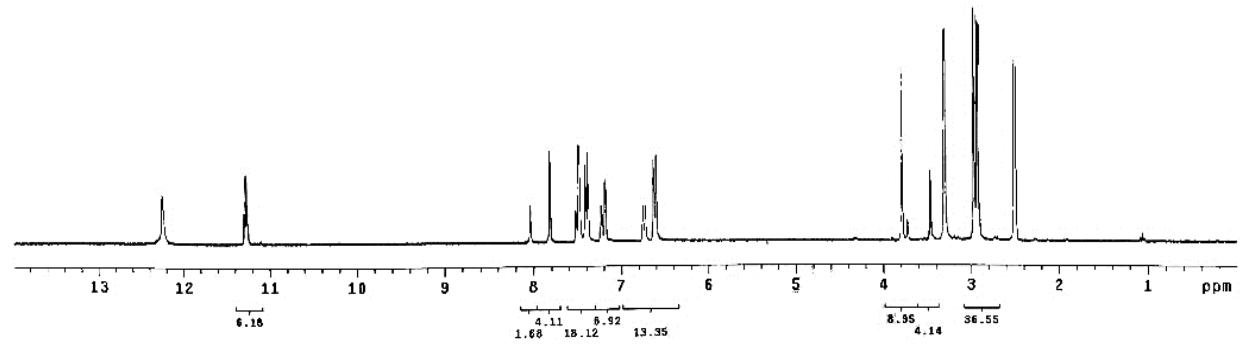

Fig.1:- ${ }^{1} \mathrm{H}$ NMR spectrum of $\mathrm{H}_{2} \mathrm{~L}$ in DMSO

The MS of $\mathrm{H}_{2} \mathrm{~L}$ displayed the molecular ion peak [M] ${ }^{+}$of $\mathrm{H}_{2} \mathrm{~L}$ at $\mathrm{m} / \mathrm{z}=331$ (17.98\%) which is equal to its molecular weight and relating to the moiety of the ligand $\left[\left(\mathrm{C}_{15} \mathrm{H}_{17} \mathrm{O}_{2} \mathrm{~N}_{5} \mathrm{~S}\right)\right.$ atomic mass 331.353].

In IR spectra of $\left[\mathrm{Ni}\left(\mathrm{H}_{2} \mathrm{~L}\right)\left(\mathrm{H}_{2} \mathrm{O}\right) \mathrm{Cl}_{2}\right] \cdot 2 \mathrm{H}_{2} \mathrm{O}$ and $\left[\mathrm{Fe}\left(\mathrm{H}_{2} \mathrm{~L}\right) \mathrm{Cl}_{3}\right] \cdot{ }_{2} \mathrm{H}_{2} \mathrm{Ocomplexes}$ displayed that the $\mathrm{H}_{2} \mathrm{Lacted}$ as a neutral tridentate ligand coordinating via $(\mathrm{C}=\mathrm{O})_{1},(\mathrm{C}=\mathrm{O})_{2}$ and $(\mathrm{C}=\mathrm{N})$. This manner of complexation wassuggested by the negative shift of $v(C=N), v(C=O)_{1}$ and $v(C=O)_{2}$. The presence of new bands at $(515 ; 519)$ and $(467 ; 472) \mathrm{cm}^{-1}$ which attributable to (M-O) and (M-N) [38],respectively(Figure 2).

Also, the IR spectrum of $\left[\mathrm{Zn}(\mathrm{HL})_{2}\right]$ complex showed that the $\mathrm{H}_{2} \mathrm{~L}$ acted as a mononegative tridentate ligand chelatingthrough $(\mathrm{C}=\mathrm{N}),(\mathrm{C}=\mathrm{O})_{1}$ and $(-\mathrm{C}=\mathrm{O}-)_{2}$. This mode of chelation was confirmed by: (i) the absence of $v(\mathrm{C}=\mathrm{O})_{2}$ and $\mathrm{v}(\mathrm{NH})_{2}$ with instantaneousappearance of new bands at 1603 and $1123 \mathrm{~cm}^{-1}$ which assignable to $v(\mathrm{C}=\mathrm{N}){ }_{2}$ and $v(=\mathrm{C}-\mathrm{O})_{2(\text { enolic) }}$, respectively [39], (ii) the negative shift of $v(\mathrm{C}=\mathrm{N})$ and $v(\mathrm{C}=\mathrm{O})_{1}$ and (iii) the existence of novel bands at521and $487 \mathrm{~cm}^{-1}$ which attributed to $v(\mathrm{Zn}-\mathrm{O})$ and $v(\mathrm{Zn}-\mathrm{N})$, respectively [38].Also, the ${ }^{1} \mathrm{H}$ NMR 
spectrum of the $\mathrm{Zn}(\mathrm{II})$ complex displayed the signal attributed to the $(\mathrm{NH})_{1}$ proton indicating that this group taken no part in coordination. However, the disappearance of signal related to $(\mathrm{NH})_{2}$ proton ensure the deprotonation of the enolized carbonyl oxygen.

Moreover, the IR spectrum of $\left[\mathrm{CuL}\left(\mathrm{H}_{2} \mathrm{O}\right)\right] \cdot 2 \mathrm{H}_{2}$ Ocomplex displayed that $\mathrm{H}_{2} \mathrm{~L}$ acted as a binegative tridentate ligand coordinating via $(=\mathrm{C}-\mathrm{O}-)_{1},(=\mathrm{C}-\mathrm{O}-)_{2}$ and $(\mathrm{C}=\mathrm{N})$. This kindwassuggested by (i) the negative shift of $(\mathrm{C}=\mathrm{N})$ to lower wavenumber, (ii) the absences of $v(\mathrm{NH})_{1}, v(\mathrm{NH})_{2}, v(\mathrm{C}=\mathrm{O})_{1}$ and $\mathrm{v}(\mathrm{C}=\mathrm{O})_{2}$ with immediatepresence of new band at $1636,1610,1170$ and $1128 \mathrm{~cm}^{-1}$ which related to $v(=\mathrm{C}-\mathrm{O})_{1(\text { enolic) })}, \quad \mathrm{v}(=\mathrm{C}-\mathrm{O})_{2(\text { enolic) }}, \quad v(\mathrm{C}=\mathrm{N})^{*}{ }_{1}$ and $v(\mathrm{C}=\mathrm{N})^{*}{ }_{2}$, respectively, and (iii) the appearance of new bands at 513 and $410 \mathrm{~cm}^{-1}$ which attributed to v(Cu-O)and v(Cu-N) respectively[39].

(A)

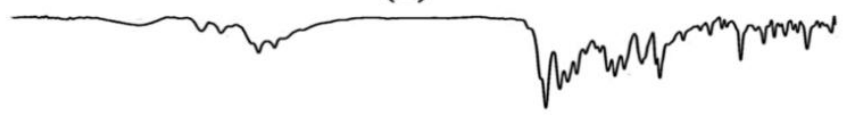

(B)

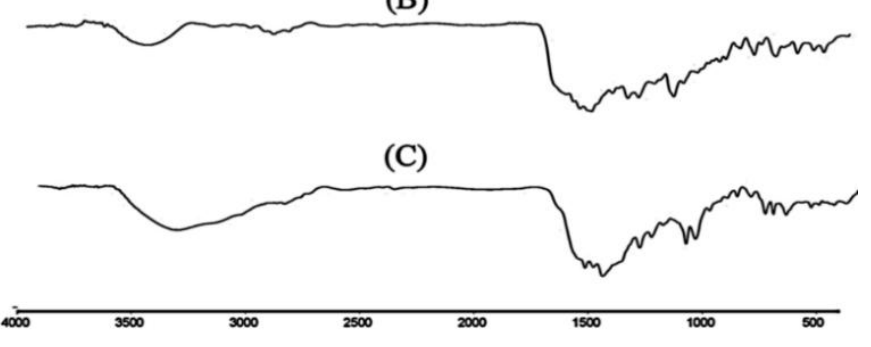

Fig.2:- Infrared spectra of (A) $\mathrm{H}_{2} \mathrm{~L}$, (B) $\left[\mathrm{CuL}\left(\mathrm{H}_{2} \mathrm{O}\right)\right] .2 \mathrm{H}_{2} \mathrm{O}$ and (C) $\left[\mathrm{Fe}\left(\mathrm{H}_{2} \mathrm{~L}\right) \mathrm{Cl}_{3}\right] .2 \mathrm{H}_{2} \mathrm{O}$

\section{Electronic spectra:-}

The electronic spectrum of $\left[\mathrm{Ni}\left(\mathrm{H}_{2} \mathrm{~L}\right)\left(\mathrm{H}_{2} \mathrm{O}\right) \mathrm{Cl}_{2}\right] \cdot 2 \mathrm{H}_{2} \mathrm{Ocomplex}$ exhibited two bands at 31446 and $21739 \mathrm{~cm}^{-}$ , assigned to ${ }^{3} \mathrm{~A}_{2} \mathrm{~g} \rightarrow{ }^{3} \mathrm{~T}_{1} \mathrm{~g}(\mathrm{~F})$ and to ${ }^{3} \mathrm{~A}_{2} \mathrm{~g} \rightarrow{ }^{3} \mathrm{~T}_{1} \mathrm{~g}(\mathrm{P})$ transitions, respectively, in an octahedral geometry (Table 3).Also,the electronic spectrum of $\left[\mathrm{CuL}\left(\mathrm{H}_{2} \mathrm{O}\right)\right] \cdot 2 \mathrm{H}_{2} \mathrm{O}$ complex exhibited a broad band with a maximum at $14286 \mathrm{~cm}^{-}$

${ }^{1}$ related to ${ }^{2} \mathrm{~B}_{1} \mathrm{~g} \rightarrow{ }^{2} \mathrm{~A}_{1} \mathrm{~g}$ transition as stated for square planar $\mathrm{Cu}(\mathrm{II})$ complex. The electronic spectrum of $\left[\mathrm{Fe}\left(\mathrm{H}_{2} \mathrm{~L}\right) \mathrm{Cl}_{3}\right] \cdot 2 \mathrm{H}_{2} \mathrm{O}$ complex displayed three bands at 12820,20408 and $25000 \mathrm{~cm}^{-1}$ ascribed to ${ }^{6} \mathrm{~A}_{1} \mathrm{~g} \rightarrow{ }^{4} \mathrm{~T}_{1} \mathrm{~g}(\mathrm{G})$, ${ }^{6} \mathrm{~A}_{1} \mathrm{~g}(\mathrm{~F}) \rightarrow{ }^{4} \mathrm{~T}_{2} \mathrm{~g}(\mathrm{G})$ and ${ }^{6} \mathrm{~A}_{1} \mathrm{~g}(\mathrm{~F}) \rightarrow{ }^{4} \mathrm{Eg}(\mathrm{G})$ transitions, respectively, in octahedral configuration[40].

Table 3:- Magnetic moments, electronic spectra and ligand field parameters of metal complexes.

\begin{tabular}{|l|l|l|l|l|l|l|}
\hline Compound & $\mu$ eff.(BM) & Bandposition $\left(\mathrm{cm}^{-1}\right)$ & Dq $\left(\mathrm{cm}^{-1}\right)$ & $\mathrm{B}\left(\mathrm{cm}^{-1}\right)$ & $\beta$ & $v_{2} / v_{1}$ \\
\hline 2 & 3.2 & $31446 ; 21739$ & 1378 & 689 & 0.709 & 1.468 \\
\hline 3 & 5.2 & $25000 ; 20408 ; 12820$ & - & - & - & - \\
\hline 5 & 2.1 & 14286 & - & - & - & - \\
\hline
\end{tabular}




\section{Geometry optimization with DFT method:-}

DFT calculations are performed to predict the molecular structure andnumbering of atoms of $\mathrm{H}_{2} \mathrm{~L}$ and its metal complexes (Structures 1).

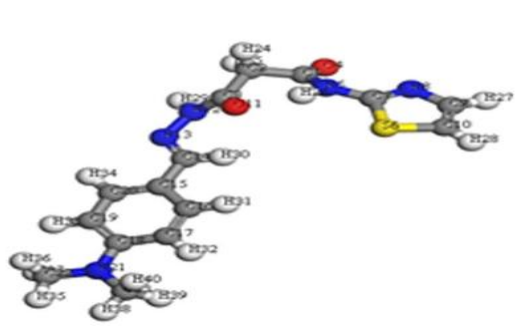

(A)

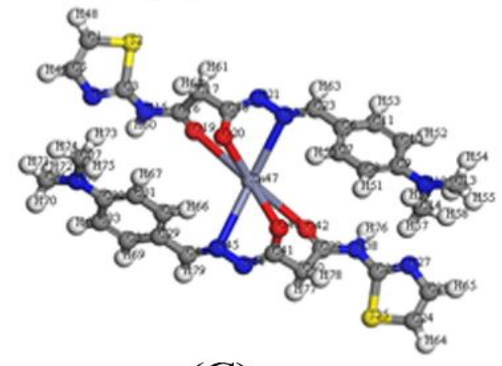

(C)

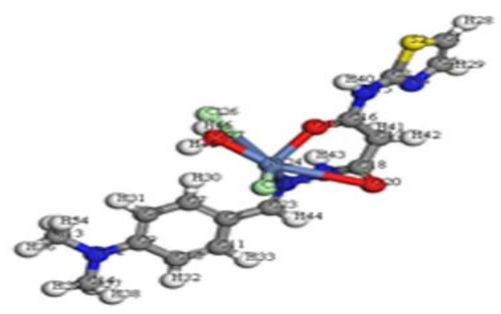

(B)

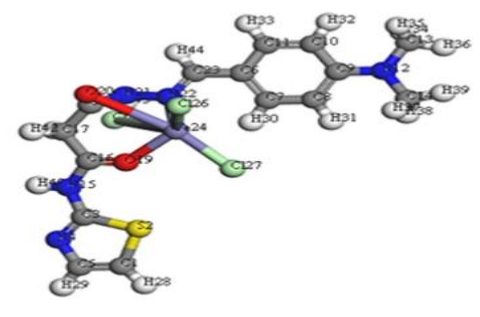

(D)

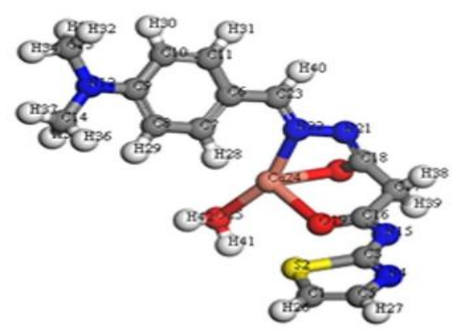

(E)

Structure 1:- Molecular modeling of (A) $\mathrm{H}_{2} \mathrm{~L}$, (B) $\left[\mathrm{Ni}\left(\mathrm{H}_{2} \mathrm{~L}\right)\left(\mathrm{H}_{2} \mathrm{O}\right) \mathrm{Cl}_{2}\right] \cdot 2 \mathrm{H}_{2} \mathrm{O}$, (C) $\left[\mathrm{Zn}(\mathrm{HL})_{2}\right]$, (D)

$\left[\mathrm{Fe}\left(\mathrm{H}_{2} \mathrm{~L}\right) \mathrm{Cl}_{3}\right] \cdot 2 \mathrm{H}_{2} \mathrm{O},(\mathrm{E})\left[\mathrm{CuL}\left(\mathrm{H}_{2} \mathrm{O}\right)\right] \cdot 2 \mathrm{H}_{2} \mathrm{O}$

\section{Molecular parameters:-}

The Quantum chemical parameters such as $\mathrm{E}_{\text {Номо }}, \mathrm{E}_{\mathrm{LUMO}}$, total energy, binding energy and dipole moment of investigated compounds were calculated (Table 4). From the outcome data we can proposed that:

* The negative values of $\mathrm{E}_{\mathrm{HOMO}}$ and $\mathrm{E}_{\mathrm{LUMO}}$ indicated to the stability of complexes (Figure 3).

* The higher binding energy value of complexes indicated the great stability of complexes.

* The higher dipole moment value $\mathrm{ofH}_{2}$ Lindicated to the free ligand was more potent biological activities than the isolated complexes.

Table 4:- The molecular parameters of the ligand and their complexes.

\begin{tabular}{|c|c|c|c|c|c|}
\hline Compound & $\begin{array}{c}\text { Total Energy } \\
(\mathrm{Ha})\end{array}$ & $\begin{array}{c}\text { Binding Energy } \\
(\mathrm{Ha})\end{array}$ & $\begin{array}{c}\text { Dipole moment } \\
(\text { debye })\end{array}$ & $\begin{array}{c}\text { HOMO } \\
(\mathrm{eV})\end{array}$ & $\begin{array}{c}\text { LUMO } \\
(\mathrm{eV})\end{array}$ \\
\hline 1 & -1404.622293 & -6.9256921 & 8.5025 & -4.719 & -2.096 \\
\hline 2 & -2595.687509 & -8.2129894 & 5.4453 & -5.435 & -2.964 \\
\hline 3 & -2929.231760 & -7.9761070 & 6.4118 & -4.264 & -3.036 \\
\hline 4 & -3063.2504092 & -14.3447502 & 2.8675 & -4.222 & -2.482 \\
\hline 5 & -1702.907849 & -7.5911838 & 8.4480 & -4.733 & -2.631 \\
\hline
\end{tabular}


HOMO

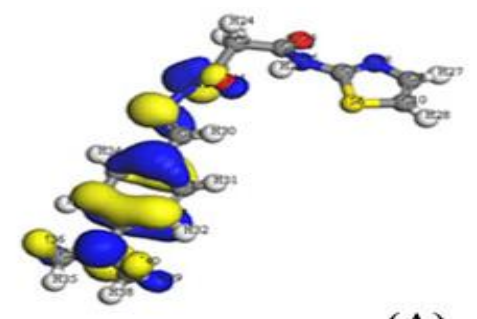

(A)
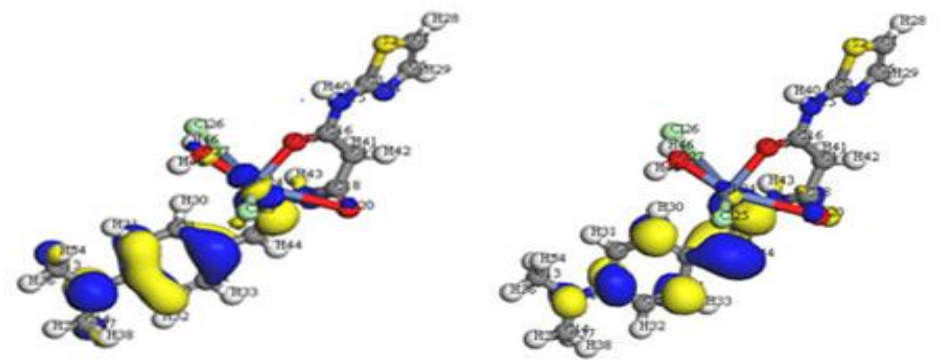

(B)
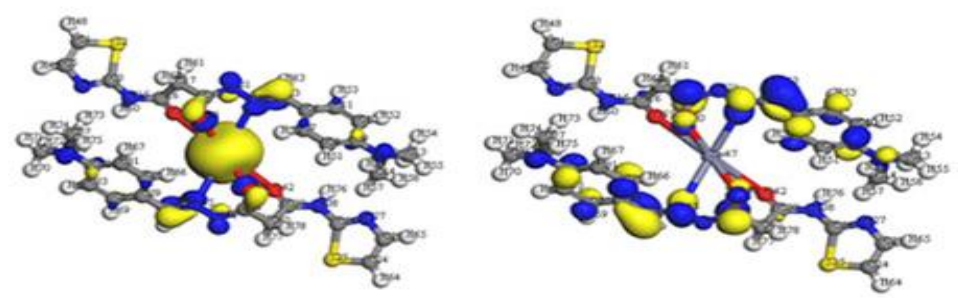

(C)
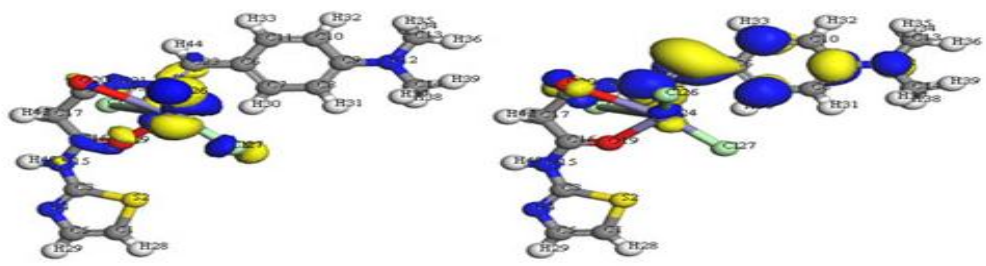

(D)
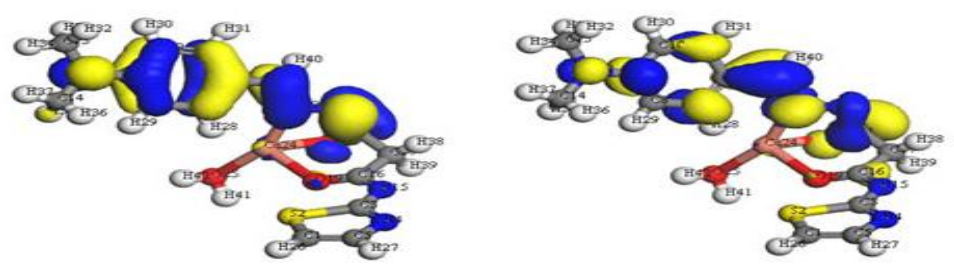

(F)

Fig.3:- The HOMO and LUMO of (A) $\mathrm{H}_{2} \mathrm{~L}$, (B) $\left[\mathrm{Ni}\left(\mathrm{H}_{2} \mathrm{~L}\right)\left(\mathrm{H}_{2} \mathrm{O}\right) \mathrm{Cl}_{2}\right] .2 \mathrm{H}_{2} \mathrm{O}$, (C) $\left[\mathrm{Zn}(\mathrm{HL})_{2}\right]$, (D) $\left[\mathrm{Fe}\left(\mathrm{H}_{2} \mathrm{~L}\right) \mathrm{Cl}_{3}\right] \cdot 2 \mathrm{H}_{2} \mathrm{O}$, and $(\mathrm{E})\left[\mathrm{CuL}\left(\mathrm{H}_{2} \mathrm{O}\right)\right] \cdot 2 \mathrm{H}_{2} \mathrm{O}$ 


\section{Molecular electrostatic potential of $\mathrm{H}_{2} \mathrm{~L}$ and its metal complexes:-}

The MEP was considered a good descriptor for significantpositions for nucleophilic and electrophilic attack [41] where 3D plots of MEP were drawn for the ligand and its metal complexes (Figure 4). According to the MEP, the area with red color indicated the electron-rich siteswhich preferredthe electrophilic attack. Conversely, the area withblue color indicated the electron-poor siteswhich preferred the nucleophilic attack [42]. While, the area with green color indicated the neutral electrostatic potential sites.

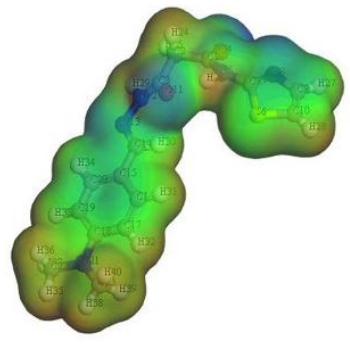

(A)

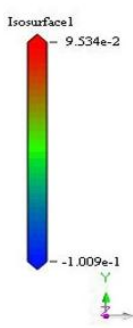

$\rightarrow$

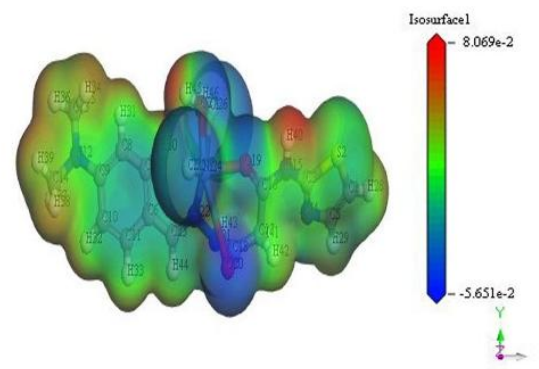

(B)

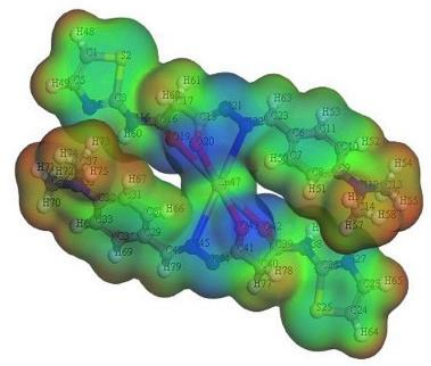

(C)

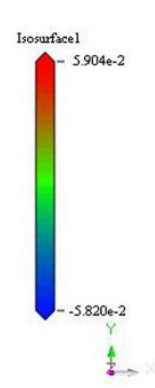

.

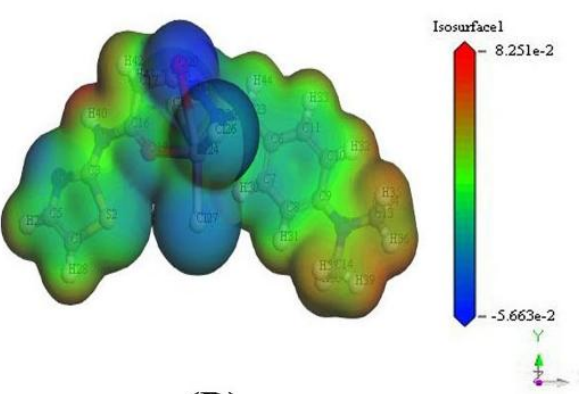

(D)

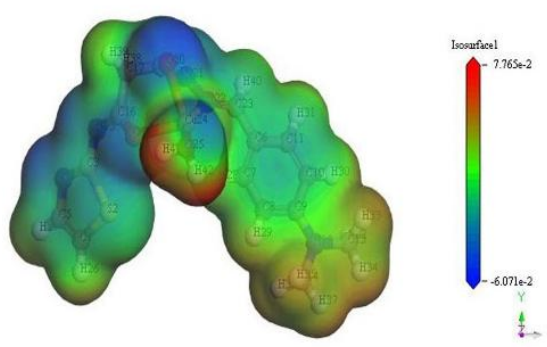

(E)

Fig.4:- Molecular electrostatic potential map for (A) $\mathrm{H}_{2} \mathrm{~L}$, (B) $\left[\mathrm{Ni}\left(\mathrm{H}_{2} \mathrm{~L}\right)\left(\mathrm{H}_{2} \mathrm{O}\right) \mathrm{Cl}_{2}\right] .2 \mathrm{H}_{2} \mathrm{O}$, (C) $\left[\mathrm{Zn}(\mathrm{HL})_{2}\right]$, (D)

$\left[\mathrm{Fe}\left(\mathrm{H}_{2} \mathrm{~L}\right) \mathrm{Cl}_{3}\right] \cdot 2 \mathrm{H}_{2} \mathrm{O}$, (E) $\left[\mathrm{CuL}\left(\mathrm{H}_{2} \mathrm{O}\right)\right] \cdot 2 \mathrm{H}_{2} \mathrm{O}$ 


\section{Biological activity:-}

The biological activity of hydrazones was encouraged us to study their complexation effect and test their activityversus economically bacterial and fungal $[43,44]$.

\section{Antifungal activity:-}

The outcomesdata revealed that the $\mathrm{H}_{2} \mathrm{~L}$ and its metal complexes have apotent activity versus Aspergillus flavus andCandida albicans(Table 5). $\mathrm{TheH}_{2} \mathrm{~L}$ and $\left[\mathrm{Ni}\left(\mathrm{H}_{2} \mathrm{~L}\right)\left(\mathrm{H}_{2} \mathrm{O}\right) \mathrm{Cl}_{2}\right] \cdot 2 \mathrm{H}_{2} \mathrm{Ocomplexhave}$ themaximumantifungal activityagainst Aspergillus flavus than Candida albicans in comparison with thestandard drug Fluconazole [45].

Table 5:- Antifungal activities of $\mathrm{H}_{2} \mathrm{~L}$ and its metal complexes in terms of MIC (mg/ml)

\begin{tabular}{|c|c|c|}
\hline Compound & C. Albicans & A. flavus \\
\hline Fluconazole & 1.56 & 0.78 \\
\hline 1 & 4.68 & 3.12 \\
\hline 2 & 1.56 & 0.78 \\
\hline 3 & 9.37 & 6.25 \\
\hline 4 & 18.75 & 12.5 \\
\hline 5 & $>100$ & $>100$ \\
\hline
\end{tabular}

\section{Antibacterial activity:-}

Also, the outcomes data revealed that the $\mathrm{H}_{2} \mathrm{~L}$ and its metal complexes have a potent antibacterial activity versus different types of bacteria in comparison with the standard drug Ciprofloxacin [46-48]. The values of MIC displayed that the $\mathrm{H}_{2} \mathrm{~L},\left[\mathrm{Ni}\left(\mathrm{H}_{2} \mathrm{~L}\right)\left(\mathrm{H}_{2} \mathrm{O}\right) \mathrm{Cl}_{2}\right] \cdot 2 \mathrm{H}_{2} \mathrm{O}$ and $\left[\mathrm{Fe}\left(\mathrm{H}_{2} \mathrm{~L}\right) \mathrm{Cl}_{3}\right] \cdot 2 \mathrm{H}_{2} \mathrm{O}$ complexes have the highest antibacterial activity (Table 6).

Table 6:- Antibacterial activities in terms of (MIC) (mg/ml)

\begin{tabular}{|c|c|c|c|c|}
\hline \multirow{2}{*}{ Compound } & \multicolumn{2}{|c|}{ Gram -Ve } & \multicolumn{2}{c|}{ Gram +Ve } \\
\cline { 2 - 5 } & E. coli & P. aeuroginosa & S. aureus & B. subtilis \\
\hline Ciprofloxacin & 1.56 & 0.78 & 1.56 & 0.39 \\
\hline 1 & 9.37 & 6.25 & 4.68 & 2.34 \\
\hline 2 & 1.56 & 0.78 & 1.56 & 1.17 \\
\hline 3 & 4.68 & 2.34 & 6.25 & 3.12 \\
\hline 4 & 12.5 & 9.37 & 12.5 & 9.37 \\
\hline 5 & $>100$ & $>100$ & $>100$ & $>100$ \\
\hline
\end{tabular}

The antioxidant activity of ligands and their metal complexes:-

The ABTS assay was applied to measure the antioxidant effect of the investigated compounds [49]. Amongst all tested compounds [ $\left.\mathrm{Ni}\left(\mathrm{H}_{2} \mathrm{~L}\right)\left(\mathrm{H}_{2} \mathrm{O}\right) \mathrm{Cl}_{2}\right] \cdot 2 \mathrm{H}_{2}$ Oconsidered the good antioxidant in comparison with standard ascorbicacid (Table 7).

Table 7:- Anti-oxidant assays by ABTS method

\begin{tabular}{|c|c|c|}
\hline \multirow{2}{*}{ Method } & \multicolumn{2}{|c|}{ ABTS } \\
\cline { 2 - 3 } & \multicolumn{2}{|c|}{ Abs(control)-Abs(test)/Abs(control)X100 } \\
\hline Compounds & Absorbance of samples & \% inhibition \\
\hline Control of ABTS & 0.51 & $0 \%$ \\
\hline Ascorbic-acid & 0.055 & $89.20 \%$ \\
\hline 1 & 0.156 & $69.40 \%$ \\
\hline 2 & 0.075 & $85.30 \%$ \\
\hline 3 & 0.22 & $56.90 \%$ \\
\hline 4 & 0.24 & $52.90 \%$ \\
\hline 5 & 0.287 & $43.70 \%$ \\
\hline
\end{tabular}


In addition, the anti-oxidant activity was tested for erythrocyte hemolysis of isolated compounds. The results revealed that $\left[\mathrm{CuL}\left(\mathrm{H}_{2} \mathrm{O}\right] \cdot 2 \mathrm{H}_{2}\right.$ Odemonstrated strong anti-oxidative activity in the hemolysis assay (Table 8).

Table 8:- Anti-oxidant assays by erythrocyte hemolysis.

\begin{tabular}{|c|c|c|}
\hline \multirow{2}{*}{ Compounds } & \multicolumn{2}{|c|}{ Erythrocyte hemolysis } \\
\cline { 2 - 3 } & \multicolumn{2}{|c|}{ A/B x 100 } \\
\cline { 2 - 3 } & Absorbance of samples (A) & \% hemolysis \\
\hline Absorbance of $\mathrm{H}_{2} \mathrm{O}(\mathrm{B})$ & 0.896 & --- \\
\hline Ascorbic-acid & 0.042 & $6.70 \%$ \\
\hline 1 & 0.538 & $59.00 \%$ \\
\hline 2 & 0.531 & $59.30 \%$ \\
\hline 3 & 0.531 & $20.00 \%$ \\
\hline 4 & 0.179 & $18.00 \%$ \\
\hline 5 & 0.161 & \\
\hline
\end{tabular}

The cytotoxicity of $\mathrm{H}_{2}$ Land its metal complexes on HCT-116 cell line:-

The cytotoxicity assays of $\mathrm{H}_{2} \mathrm{~L}$ and its metal complexes versusHCT-116 (human colorectal carcinoma cells lines) weredemonstrated in (Table 9). The results showedthat $\left[\mathrm{Ni}\left(\mathrm{H}_{2} \mathrm{~L}\right)\left(\mathrm{H}_{2} \mathrm{O}\right) \mathrm{Cl}_{2}\right] \cdot 2 \mathrm{H}_{2} \mathrm{O}(\mathrm{IC} 50=7.7 \pm 0.68 \mu \mathrm{M}$ ) hasgreater inhibitoryinfluence than the other investigated compounds. But, $\left[\mathrm{CuL}\left(\mathrm{H}_{2} \mathrm{O}\right)\right] \cdot 2 \mathrm{H}_{2} \mathrm{O}$ complex has lower inhibitory influence $(\mathrm{IC} 50=72.8 \pm 4.76 \mu \mathrm{g} / \mathrm{ml})$ nearly no activity [50].

Table 9: Cytotoxicity (IC50) of tested compounds on HC

\begin{tabular}{|c|c|}
\hline Compounds & In vitro Cytotoxicity IC50 $(\mu \mathrm{g} / \mathrm{ml}) \bullet$ \\
\hline & HCT-116 \\
\hline 5 -FU & $5.2 \pm 0.31$ \\
\hline 1 & $13.1 \pm 1.47$ \\
\hline 2 & $7.7 \pm 0.68$ \\
\hline 3 & $10.7 \pm 1.24$ \\
\hline 4 & $16.0 \pm 1.73$ \\
\hline 5 & $72.8 \pm 4.76$ \\
\hline
\end{tabular}

\section{Ion-flotation separation:-}

\section{Influence of initial pH:-}

Many experiments were carried out to study the relation between the floatability of metal ions $\left(2 \times 10^{-4} \mathrm{~mol} \mathrm{~L}^{-1}\right)$ and $\mathrm{H}_{2} \mathrm{~L}\left(2 \times 10^{-4} \mathrm{~mol} \mathrm{~L}^{-1}\right)$ and HOL $\left(1 \times 10^{-3} \mathrm{~mol} \mathrm{~L}^{-1}\right)$. The outcomes datapresented that the greater floatability in $(6-10)$ $\mathrm{pH}$ range for $\mathrm{Cu}(\mathrm{II})$ and (5-10) for $\mathrm{Zn}(\mathrm{II})$ ions (Figure 5). This enablesus to use the prepared ligand to separatethe metal ions from various media.
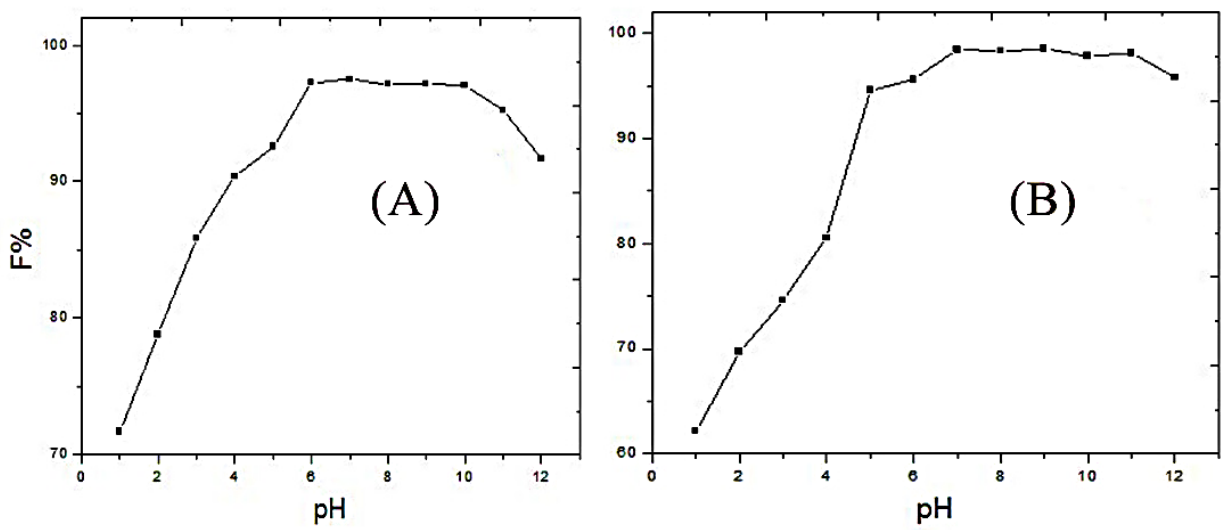

Fig.5:- .Influence of $\mathrm{pH}$ on the floatability of $2 \times 10^{-4} \mathrm{~mol} . \mathrm{L}^{-1}$ (A) $\mathrm{Cu}(\mathrm{II})$ and (B) $\mathrm{Zn}$ (II) ions using $2 \times 10^{-4} \mathrm{~mol} . \mathrm{L}^{-1}$ of ligand and $1 \times 10^{-3} \mathrm{~mol} \cdot \mathrm{L}^{-1} \mathrm{HOL}$ 


\section{Influence of initial metal concentration:-}

Many trailswere applied to float various concentrations of $\mathrm{Cu}$ (II) andZn (II) ionsin presence of $\left(2 \times 10^{-4} \mathrm{~mol} \mathrm{~L}^{-1}\right) \mathrm{H}_{2} \mathrm{~L}$ and $\left(1 \times 10^{-3} \mathrm{~mol} \mathrm{~L}^{-1}\right) \mathrm{HOL}$ at $\mathrm{pH} \sim 7$. The maximum flotation efficiency of $\mathrm{Cu}$ (II) andZn (II) ions was detected for $\mathrm{H}_{2} \mathrm{~L}$ when the ratio of $\mathrm{M}: \mathrm{L}$ is (1:1) (Figure 6). The chelating agent provided quantitative separation of $\mathrm{Cu}$ (II) andZn (II) ions $(\sim 100 \%)$ thatattributed to the existence of enoughquantities of $\mathrm{H}_{2} \mathrm{~L}$ to bind all $\mathrm{Cu}$ (II) andZn (II) ions. So, the ratio of M:Lof (1:1) was used throughout.
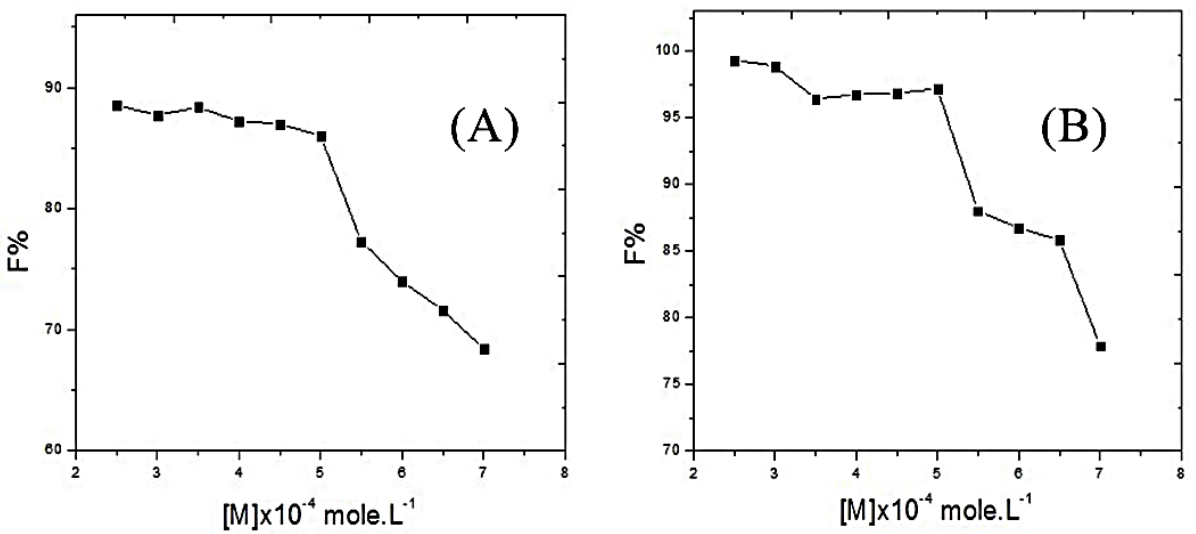

Fig. 6:- Floatability of different concentrations of (A) $\mathrm{Cu}$ (II)and (B) $\mathrm{Zn}$ (II) ions using $2 \times 10^{-4} \mathrm{~mol}^{-\mathrm{L}^{-1}}$ of prepared ligand and $1 \times 10^{-3} \mathrm{~mol} . \mathrm{L}^{-1} \mathrm{HOL}$ at $\mathrm{pH} \sim 7$

\section{Influence of ligand concentration:-}

The effect of various concentrations of $\mathrm{H}_{2} \mathrm{~L}$ towards $\mathrm{Cu}(\mathrm{II})$ and $\mathrm{Zn}(\mathrm{II})$ ions was tested to measure the collecting ability of the ligand on the floatability of the analytes at $\mathrm{pH} 7$ in presence of $1 \times 10^{-3} \mathrm{~mol} \mathrm{~L}^{-1}$ of HOL. The outcomes data shown that, the floatability of $\mathrm{Cu}$ (II) andZn (II) ions increases sharply until reaching its maximum value at $\mathrm{M}: \mathrm{L}$ ratio of (1:1) (Figure 7). Extra ligand has no opposing effect on the flotation process, therefore $2 \times 10^{-4} \mathrm{~mol} \mathrm{~L}^{-1}$ of $\mathrm{H}_{2} \mathrm{~L}$ was used throughout.
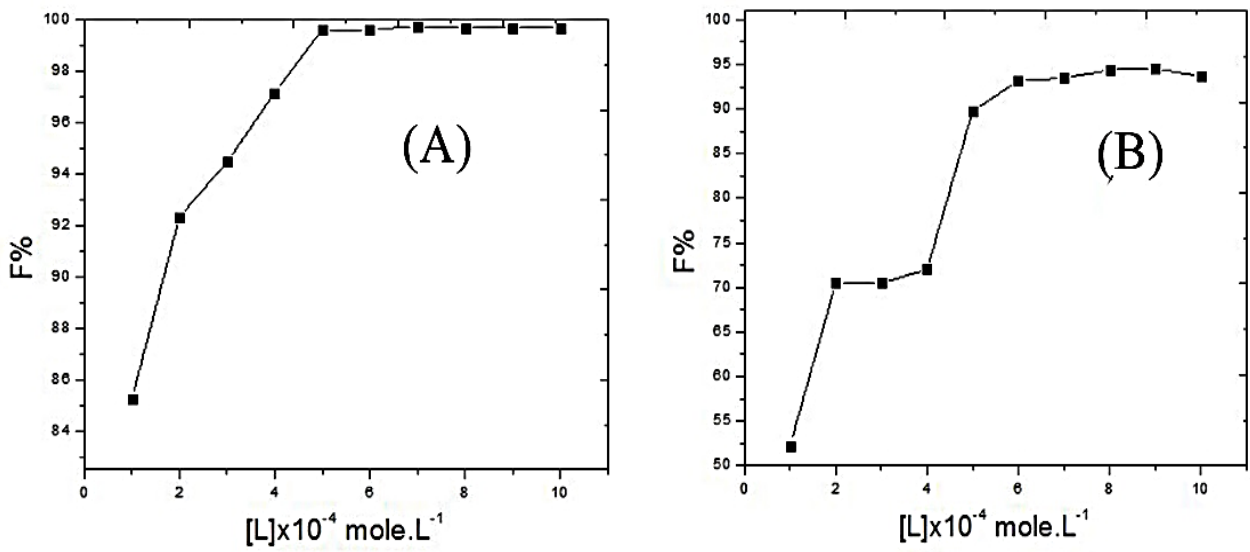

Fig. 7:- Floatability of $2 \times 10^{-4}$ mol. $\mathrm{L}^{-1}$ (A) $\mathrm{Cu}$ (II)and (B) $\mathrm{Zn}$ (II)ions using different concentrations of prepared ligand and $1 \times 10^{-3}$ mol. $\mathrm{L}^{-1} \mathrm{HOL}$ at $\mathrm{pH} \sim 7$

\section{Influence of surfactant concentration:-}

Many trials were achieved to float $\mathrm{Cu}$ (II) andZn (II) ions with HOL only, but the recovery did not go above $43 \%$. Therefore, additionalruns of experiments were occurredat $\mathrm{pH} \sim 7$ to float $2 \times 10^{-4} \mathrm{~mol} \mathrm{~L}^{-1} \mathrm{Cu}$ (II) and $\mathrm{Zn}$ (II) ions in the existence of $2 \times 10^{-4} \mathrm{~mol} \mathrm{~L}^{-1}$ of $\mathrm{H}_{2} \mathrm{~L}$ and various concentrations of HOL $\left(1 \times 10^{-3}-5 \times 10^{-2} \mathrm{~mol} \mathrm{~L}^{-1}\right)$. The outcomesdata showed the highest floatation $\%$ of $\mathrm{Cu}$ (II) andZn (II) ions in $\left(1 \times 10^{-3}-9 \times 10^{-3} \mathrm{~mol} \mathrm{~L}^{-1}\right)$ concentration range of $\mathrm{HOL}$ (Figure 8). 
The incomplete separation of $\mathrm{Cu}(\mathrm{II})$ and $\mathrm{Zn}$ (II) ions at higher concentration of surfactant was due to the surfactant changes the state of the $\mathrm{Cu}$ (II)-ligand and $\mathrm{Zn}$ (II)-ligand particles. An increase of HOL quantity was added to redispersion the coagulated precipitatevia coagulation flotation. Moreover, at high concentration of surfactant the weak flotation was occurred by the formation of a stable, hydrated envelope of surfactant orby forming a hydrate micelle coating on the solid surface on the air bubble surface [51, 52]. Therefore, the hydrophobicity of the surface was not appropriate for flotation. So, a $1 \times 10^{-3} \mathrm{~mol} \mathrm{~L}^{-1}$ concentration of HOL was fixed throughout.
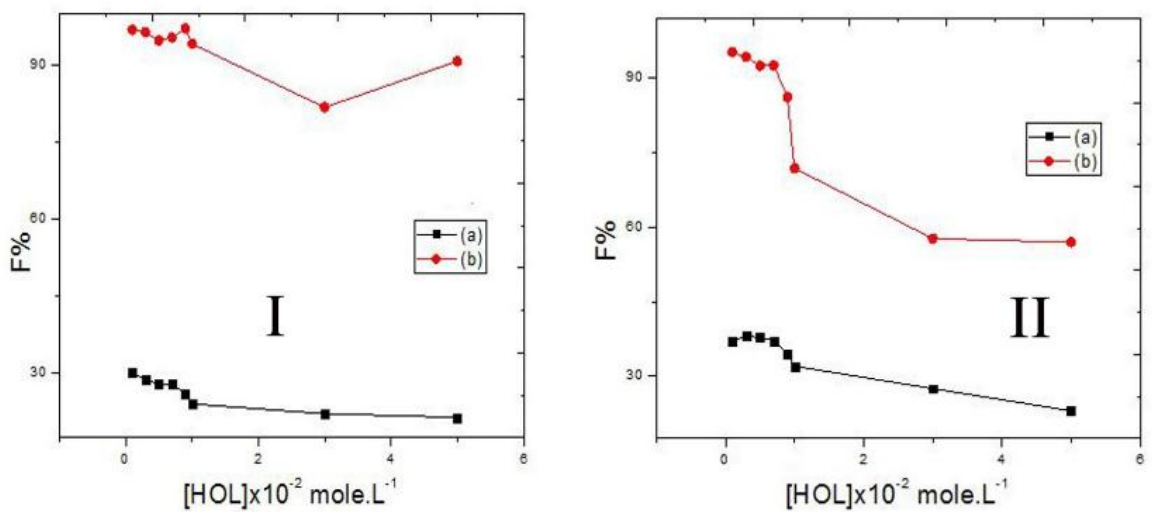

Fig. 8:- Floatability of $2 \times 10^{-4} \mathrm{~mol} \mathrm{~L}^{-1} 1$ (I) $\mathrm{Cu}^{2+}$ and (II) $\mathrm{Zn}^{+2}$ ions (a) in absence of HOL (b) in presence of different concentrations of $\mathrm{HOL}$ and $2 \times 10^{-4} \mathrm{~mol} \mathrm{~L}^{-1}$ of ligand atpH $\sim 7$.

\section{Influence of temperature:-}

In a wide range of temperature $\left(10-80{ }^{\circ} \mathrm{C}\right.$ ) aseries of experimentations was carried out to float $\mathrm{Cu}$ (II) andZn(II) ions under the optional conditions. For this purpose, solutionsofCu(II), $\mathrm{Zn}$ (II) ions, $\mathrm{H}_{2} \mathrm{~L}$ and $\mathrm{HOL}$ were either heated or cooled to the similar temperature in a water bath. Where in this step the HOL solution was decanted into $\mathrm{Cu}$ (II) andZn(II) ions solution. The mix was presented into the flotation cell jacketed with $1 \mathrm{~cm}$ thick fiberglass insulation. The maximum flotation of $\mathrm{Cu}$ (II) andZn (II) ions in $15-80^{\circ} \mathrm{C}$ range was presented in (Figure 9). So, the temperature of $25^{\circ} \mathrm{C}$ was used throughout. The decrease in separation by increasing temperature further than $80^{\circ} \mathrm{C}$ may be due to the increase in solubility of the precipitate and the instability of the foam giving rise to partial dissolution of the precipitate and deficient foam constancy to delay the precipitate [53].
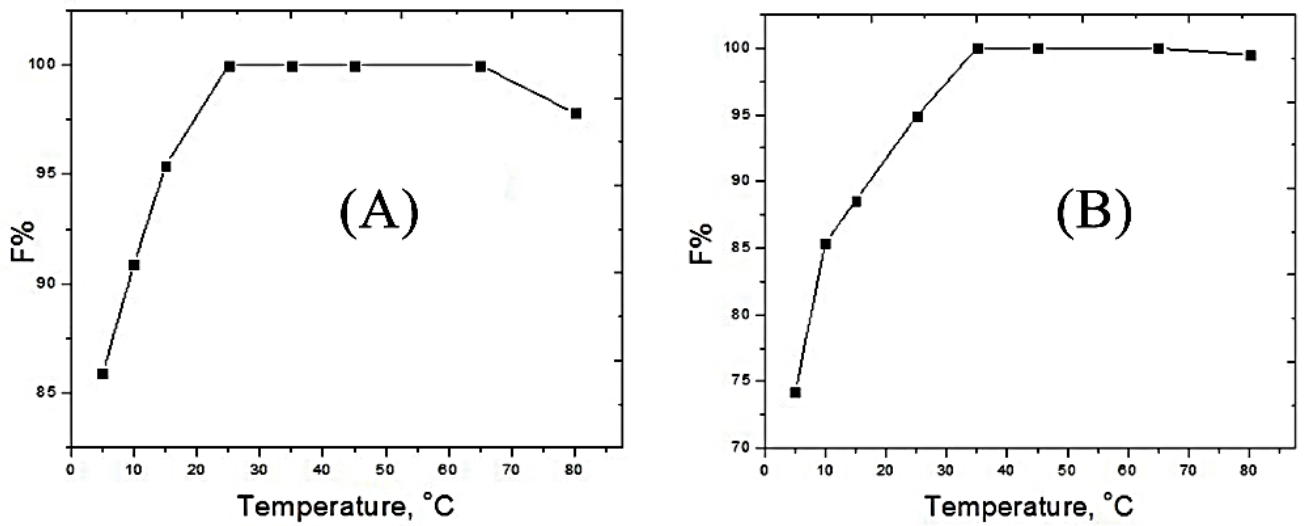

Fig. 9:- Floatability of $2 \times 10-4$ mol. $\mathrm{L}^{-1}(\mathrm{~A}) \mathrm{Cu}$ (II) and (B) Zn (II) ions at different temperatures using $2 \times 10-4 \mathrm{~mol} . \mathrm{L}^{-1}$ of prepared ligand and $1 \times 10^{-3}$ mol. $\mathrm{L}^{-1} \mathrm{HOL}$ at $\mathrm{pH} \sim 7$

Interference of thepresence of foreign ions:-

The removal percentage of $10 \mathrm{mg} \mathrm{L}^{-1} \mathrm{Cu}(\mathrm{II})$ or $\mathrm{Zn}(\mathrm{II})$ ) ions from a solution of $30 \mathrm{mg} \mathrm{L}^{-1}$ of $\mathrm{H}_{2} \mathrm{~L}$ was studied in the presence of high concentrations of differentanions and cations at $\mathrm{pH}$ 7. The usedquantities of each ion, giving an error of $\pm 4 \%$ in the removal efficiency of $\mathrm{Cu}$ (II) orZn(II) ions were recorded in (Table 10). Examination of the data shown that, all the foreign ions with relatively high concentrations in comparison with that of $\mathrm{Cu}$ (II) andZn (II) ions have no effect on the flotation of copper (II) or zinc (II). So, the suggestedmethod may find its applications on water samples. 
Table 10:- Effects of the foreign ions on the removal percentage of the examined metal ions

\begin{tabular}{|l|l|l|l|}
\hline Foreign ions & ${ }^{*}$ I/Aratio $\left({\left.\mathrm{mg} . \mathrm{L}^{-1}\right)}^{-1}\right.$ & $\operatorname{Re} \%$ of $\left(\mathrm{Cu}^{2+}\right)$ & $\operatorname{Re} \% \mathrm{of}^{\left(\mathrm{Zn}^{2+}\right)}$ \\
\hline $\mathrm{Na}^{+}$ & 25 & 99.3 & 100 \\
\hline $\mathrm{K}^{+}$ & 45 & 98.4 & 98.8 \\
\hline $\mathrm{Mg}^{2+}$ & 35 & 100 & 97.9 \\
\hline $\mathrm{Ca}^{2+}$ & 30 & 97.5 & 98.9 \\
\hline $\mathrm{Cl}^{-}$ & 30 & 98.4 & 99.1 \\
\hline $\mathrm{SO}_{4}{ }^{2-}$ & 20 & 94.9 & 98.8 \\
\hline $\mathrm{HCO}_{3}^{-}$ & 25 & 99.5 & 98.9 \\
\hline $\mathrm{CH}_{3} \mathrm{COO}^{-}$ & 40 & 99.2 & 97.5 \\
\hline
\end{tabular}

$* \mathrm{I} / \mathrm{A}=$ interference/ analyte ratio

\section{Application:-}

To investigate the applicability of the suggestedmethod, a number of trials were performed to recover $15 \mathrm{mg} \mathrm{L} \mathrm{L}^{-1}$ of $\mathrm{Cu}$ (II) andZn (II) ions poured to $1 \mathrm{~L}$ of aqueous and some water samples. The experiments of flotation were performed by using $50 \mathrm{ml}$ clear, filtered, uncontaminated sample solutions at $\mathrm{pH}$ 7. The outcomes datadisplayed that the recovery was acceptable and quantitative under the suggested conditions of the applied flotation technique (Table 11).

Table 11: Recovery of $15 \mathrm{mg} \mathrm{L}^{-1}$ of studied metal ions from some water samples.

\begin{tabular}{|c|c|c|c|}
\hline Water samples (location) & Added metal $\left(\mathrm{mg} . \mathrm{L}^{-1}\right)$ & $\mathrm{Re} \%$ of $\mathrm{Cu}^{2+}$ & $\mathrm{Re}^{2+}$ of $\mathrm{Zn}^{2+}$ \\
\hline Sharm El-Shiekh & 15 & 98.57143 & 85.97368 \\
\hline Alexandria & 15 & 97.71429 & 80.23684 \\
\hline New Valley & 15 & 99.11905 & 77.89474 \\
\hline Mansoura & 15 & 98.78571 & 83.65789 \\
\hline
\end{tabular}

\section{Suggested flotation mechanism:-}

The mechanism of the flotation of metal-ligand precipitates wasproposed depending on the following facts:

* $\mathrm{Cu}(\mathrm{II})$ and $\mathrm{Zn}(\mathrm{II})$ reacted with $\mathrm{H}_{2} \mathrm{~L}$ in a $\mathrm{M}: \mathrm{L}$ ratio of (1:1) to provide the complex $\mathrm{M}_{2} \mathrm{~L}$ according to this equation:

$$
\mathrm{M}^{2+}+\mathrm{H}_{2} \mathrm{~L}=\mathrm{M}_{2} \mathrm{~L}+2 \mathrm{H}^{+}
$$

The $\mathrm{H}_{2} \mathrm{~L}$ has severaldonating sites, as carbonyl oxygen $(\mathrm{C}=\mathrm{O})$, azomethine nitrogen $(\mathrm{C}=\mathrm{N})($ Scheme 1$)$.

* HOLstarted to dissociate at pH > 5.2 [54] and the percentage of various forms of oleic acid weredetected by infra-red analysis (Table 12). The infra-red spectra of oleic acid with changing pH showed that at 1300-1800 $\mathrm{cm}^{-1}$, there are bands characteristic of the $\mathrm{COOH}$ and $\mathrm{CO}^{2-}$ groups associated with $\mathrm{Na}+$ [55]. These informationapprovethe reported data, [56] that the $(\mathrm{C}=\mathrm{O})$ stretching band of oleic acid at $1705 \mathrm{~cm}^{-1}$ was shifted to bands in the range $1520-1540 \mathrm{~cm}^{-1}$ for sodium oleate on ionization. So, oleic acid can interact with extra systems, viahydrogen bonding, either in its undissociated (R-COOH) or dissociated (R-COO`) forms depending on the $\mathrm{pH}$ of the medium and according to thisequations:

$$
\begin{aligned}
& \mathrm{R}-\mathrm{COOH}+\mathrm{MHL}^{+}=\mathrm{R}-\mathrm{COOH}+\mathrm{LHM}^{+} \\
& \mathrm{R}-\mathrm{COO}^{-}+\mathrm{MHL}^{+}=\mathrm{R}-\mathrm{COO}+\mathrm{LHM}^{+}
\end{aligned}
$$

The combination of oleic acid surfactant with the copper-ligand or zinc-ligand chelate provided hydrophobic aggregates that float with the assistance of air bubbles to the solution surface by slight shaking [57].

Table 12:- Different forms of oleic acid determined by spectrophotometric

\begin{tabular}{|c|c|c|c|c|}
\hline $\mathrm{pH}$ & & $(\%)$ & & Total \\
\hline & $\mathrm{HOL}$ & $\mathrm{Ol}^{-}$ & $\mathrm{NaOL}$ & \\
\hline 5.2 & 100.0 & 0.0 & 0.0 & 100.0 \\
\hline 8.0 & 6.5 & 34.2 & 0.0 & 100.0 \\
\hline 8.2 & 38.5 & 57.7 & 3.8 & 100.0 \\
\hline 9.0 & 13.6 & 68.2 & 18.2 & 100.0 \\
\hline 11.5 & 0.0 & 80.0 & 20.0 & 100.0 \\
\hline 12.0 & 0.0 & 52.2 & 47.8 & 100.0 \\
\hline
\end{tabular}




\section{References:-}

1. Mohanty D, The antibacterial activities of thiazoles, substituted thiazoles and their metal Complexes. Current Pharma Research 2012; 3(1):750-763.

2. Saini R, Kumar V, Gupta A, Gupta G. Synthesis, characterization, and antibacterial activity of a novel heterocyclic Schiff's base and its metal complexes of first transition series.Med Chem Res2014; 23:690-698.

3. Bhava P,Tharmaraj P, Muthuraj V, Umadevi M. Synthesis, characterization and biological activities of transition metal chelates of 2-aminothiazole-derived Mannich bases. IOSR Journal of Engineering 2013; 3:2250-3021.

4. Raja S. Synthesis, spectroscopic characterization, analgesic, and antimicrobial activities of $\mathrm{Co}(\mathrm{II}), \mathrm{Ni}(\mathrm{II})$, and $\mathrm{Cu}$ (II) complexes of 2-[N,N-bis-(3,5-dimethyl-pyrazolyl-1- methyl)]aminothiazole. Med Chem Res 2015; 24:1578-1585

5. Thakar A, Pandya K, Joshi K, Pancholi A. Synthesis, Characterization and Antibacterial Activity of Novel Schiff Bases Derived from4-Phenyl-2-aminothiazole and their Mn(II), Fe(II), Co(II), Ni(II) and Cu(II) Metal complexes. E-Journal of Chemistry 2011; 8(4):1556-1565

6. Wu Y, Jiang Z, Hu B, Duan J. Electrothermal vaporization inductively coupled plasma atomic emission spectrometry determination of gold, palladium, and platinum using chelating resin YPA4 as both extractant and chemical modifier. Talanta 2004;63:585-92.

7. Qing Y, Hang Y, Wanjaul R, Jiang Z, Hu B. Adsorption behavior of Noble metal ions ( $\mathrm{Au}, \mathrm{Ag}, \mathrm{Pd})$ on nanometer-size titanium dioxide with ICP-AES. Anal Sci 2003;19:1417-20.

8. Yin $\mathrm{P}, \mathrm{Xu} \mathrm{Q}, \mathrm{Qu} \mathrm{R}, \mathrm{Zhao} \mathrm{G}$, Sun Y. Adsorption of transition metal ions from aqueous solutions onto a novel silica gel matrix inorganic-organic composite material. J Hazard Mater 2010;173:710-6.

9. Chand R, Watari T, Inoue K, Kawakita H, Luitel HN, Parajuli D, et al. Selective adsorption of precious metal from hydrochloric acid solutions using porous carbon prepared from barley straw and rice husk. Miner Eng 2009;22:1277-82.

10. Soylak M, Tuzen M. Coprecipitation of gold(III), palladium(II) and lead(II) for their flame atomic absorption spectrometric determinations. J Hazard Mater 2008;152:656-61.

11. Ghazy S E, Mostafa H A, El-Farra, S A, Fouda, A S. Flotation-separation of nickel(II) from aqueous media using some hydrazone derivatives as organic collectors and oleic acid as surfactant, Indian J Chem Technol, 2004;11:787-792.

12. Fenglian Fu, Wang Qi.Removal of heavy metal ions from wastewaters.Journal of Environmental Management 2011;92:407-418.

13. Ulewicz M, Walkowiak W, Bartsch R. Ion flotation of zinc(II) and cadmium(II) with proton-ionizable lariat ethers-Effect of cavity size. Separation and Purification Technology. 2006;48:264-269.

14. Polat H, Erdogan D.Heavy metal removal from waste waters by ion flotation.Journal of Hazardous Materials. 2007;148:267-273.

15. Ibrahim K, Zaky R, Gomaa E, El-Hady M. Spectral, Magnetic, Thermal studies and Antimicrobial activity of (E)-3-(2-Benzylidenehydrazinyl)-3-oxo-N-(Thiazol-2-yl) Propanamide complexes . Research Journal of Pharmaceutical, Biological and Chemical Sciences 2011;2(3):391-404.

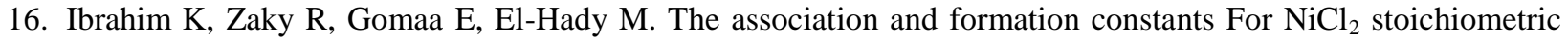
complexes with (E)-3-(2-benzylidene hydrazinyl)-3-oxo-N-(thiazol-2-yl)propanamide. Anaele Universitatii din Bucuresti 2011;20(2):149-154.

17. El-Hady M, Zaky R, Ibrahim K, Gomaa E. (E)-3-(2-(furan-ylmethylene)hydrazinyl)-3-oxo-N-(thiazol2yl)propanamide complexes: Synthesis, characterization and antimicrobial studies. Journal of Molecular Structure 2012;1016:169-180.

18. Ibrahim K, Gomaa E, Zaky R, El-Hady M. The association and formation constants for $\mathrm{CuCl}_{2}$ stoichiometric complexes with (E)-3-(2-Benzylidene Hydrazinyl)-3-oxo-N-(thiazol-2-yl)propanamide in absolute ethanol solution 294.15 K. American Journal of Chemistry 2012;2(2):23-26.

19. Ibrahim K, Zaky R, Gomaa E, El-Hady M. Physicochemical studies and biological evaluation on (E)-3-(2-(1-(2hydroxyphenyl) hydrazinyl)-3-oxo-N-(thiazol-2yl)propanamide complexes. Spectrochimica Acta Part A 2013; 107:133-144.

20. Vogel A I, Quantitative Inorganic Analysis, Longmans, London, 1989.

21. Delley B, Phys Rev. 2002;65:85403-8509.

22. Modeling and Simulation Solutions for Chemicals and Materials Research, Materials Studio (Version 5.0), Accelrys software Inc., San Diego, USA. Available online at: www.accelrys.com 2009.

23. Hehre W J, Radom L, Schlyer P V R, Pople J A, Ab Initio Molecular Orbital Theory, Wiley, New York 1986. 
24. Kessi A Delley B. Density Functional Crystal vs. Cluster Models as Applied to Zeolites. International Journal of Quantum Chemistry 1998; 68:135-144.

25. Hammer B, Hansen L B, Nørskov J K. Mproved adsorption energetics within density-functional theory using revised Perdew-Burke-Ernzerhof functionals. Phys. Rev. B 1999;59:7413-7421.

26. Matveev A, Staufer M, Mayer M, Rösch N. Density functional study of small molecules and transition-metal carbonyls using revised PBE functionals. Int. J. Quantum Chem 1999;75:863-873.

27. Hawkey P M, Lewis D A. Medical batteriology-a Practical Approach. Oxford University Press, United Kingdom 1994:181-194.

28. Mosmann T, Rapid Colorimetric Assay for Cellular Growth and Survival: Application to Proliferation and Cytotoxicity Assays. Journal of lmmunological Methods 1983;65:55-63.

29. Lissi E, Modak B, Torres R, Escobar J, Urzua, A. Total antioxidant potential of resinous exudates from Heliotropium species, and a comparison of the ABTS and DPPH methods. Free Radical Res 1999;30:471-477.

30. El-Gazzar A, Youssef M, Youssef A, Abu-Hashem A, Badria F. Design and synthesis of azolopyrimidoquinolines, pyrimidoquinazolines as anti-oxidant, anti-inflammatory and analgesic activities. Eur J Med Chem 2009; 44:609-624.

31. Aeschlach R, Loliger J, Scott C, Murcia A, Butler J, Halliwell B, Aruoma I. Antioxidant actions of thymol, carvacrol, 6-gingerol, zingerone and hydroxytyrosol. Food Chem. Toxicol 1994;32:31-36.

32. Denizot F, Lang R. Rapid colorimetric assay for cell growth and survival. J. Immunol. Methods. 1986;89:271277.

33. Mauceri H , Hanna N, Beckett M , Gorski D, Staba M , Stellato K, Bigelow K, Heimann R, Gately S, Dhanabal M, Soff G, Sukhatme V, Kufe D, Weichselbaum R. Combined effects of agiostatin and ionizing radiation in antitumour therapy. 1998;394:287-291.

34. Morimoto Y, Tanaka K, Iwakiri Y, Tokuhiro S, Fukushima S, Takeuchi Y. Protective effects of some neutral amino acids against hypotonic hemolysis. Biol Pharm Bull 1995;18:417-1422.

35. Ibrahim K, Gabr I, Abu El-Reash G, Zaky R. Spectral, magnetic, thermal, antimicrobial, and eukaryotic DNA studies on acetone [N-(3-hydroxy-2-naphthoyl)] hydrazone complexe. Monatsh Chem 2009; 140:625-632.

36. Ibrahim K, Zaky K, Gomma E, El-Hady M. Spectral, magnetic, thermal studies and antimicrobial activity of (E)-3-(2-benzylidenehydrazinyl)-3-oxo-N-(thiazol-2-yl) propanamide complexes. Res J Pharm Biol Chem Sci 2011;2:391-404.

37. Pretsch E, Bühlmann P, Badertscher M, Structure Determination of Organic Compounds, 4th, Berlin, Heidelberg, 2009.

38. Zaky R. Synthesis, Characterization, Antimicrobial, and Genotoxicity Activities of Acetoacetanilide-4-ethyl Thiosemicarbazone Complexes. Phosphorus, Sulfur, and Silicon 2011;186:365-380.

39. Zaky R, Yousef T, Spectral, magnetic, thermal, molecular modelling, ESR studies and antimicrobial activity of (E)-3-(2-(2-hydroxybenzylidene) hydrazinyl)-3-oxo-n (thiazole-2-yl) propanamide complexes. Journal of Molecular Structure 2011;1002:76-85.

40. Cotton F A, Wilkinson G, Murillo C A, Bochmann M, Advanced Inorganic Chemistry, 6th ed., John Wiley \& Sons Inc., 2003.

41. Zalaoglu Y, Ulgen A, Terzioglu C, Yildirim G. Theoretical study on the characterization of 6-methyl1,2,3,4tetrahydroquinoline using quantum mechanical calculation methods. Fen Bilimleri Dergisi 2010;14:66-76.

42. Tanak H, Köysal Y, Iş1k Ş, Yaman H, Ahsen V. Experimental and Computational Approaches to the Molecular Structure of 3-(2-Mercaptopyridine)phthalonitrile. Bull. Korean Chem 2011; 32:673-680.

43. Filipović N, Borrmann H, Todorović T, Borna M, Spasojević V, Sladić D, Novaković I,Andjelković A. Inorganica Chimica Acta 2009;362:1996-2000.

44. Thimmaiah N, Chandrappa T, Jayarama R. Structural studies of biologically active complexes of zinc(II), cadmium(II), mercury(II) and copper(II) with p-anisaldehyde thiosemicarbozone. 1984; 3:1237-1239.

45. Nagar R .Syntheses, characterization, and microbial activity of some transition metal complexes involving potentially active $\mathrm{O}$ and $\mathrm{N}$ donor heterocyclic ligands. Journal of Inorganic Biochemistry. 1990;40:349-356.

46. Johari R B, Sharma R C, J Indian Chem Soc. 1988;65:793-794.

47. Abd El-Wahab Z, El-Sarrag M. Derivatives of phosphate Schiff base transition metal complexes: synthesis, studies and biological activity.Spectrochimica Acta A 2004 ;60:271-277.

48. Panchal P, Parekh H, Patel M, Preparation, characterization and toxic activity of oxovanadium(IV) mixed ligand complexes. Toxicol. Environ. Chem 2005;87:313-320.

49. Kostova I, Saso C. Advances in Research of Schiff-Base Metal Complexes as Potent Antioxidants. Curr. Med. Chem 2013; 0:4609-4632. 
50. Yousef A, Badria F, Ghazy S, El-Gammal O, Abu El-Reash G. In vitro and in vivo antitumor activity of some synthesized 4-(2-pyridyl)-3-Thiosemicarbazides derivatives. J. Medicine and Medical Sci 2011;3: 37-46.

51. Ghazy S E, Samra S E, Mahdy A M, El-Morsy. Removal of aluminum from some water samples by sorptiveflotation using powdered modified activated carbon as sorbent and oleic acid as surfactant. Anal. Sci.2006; 22:377-382.

52. Klassen V I, Mokrousov V A. An Introduction to the Theory of Flotation. Butterworths, London (1963).

53. Ghazy S E, Mostafa G A. Flotation-Separation of Chromium(VI) and Chromium(III) from Water and Leathers Tanning Wastev Using Active Charcoal and Oleic Acid Surfactant.Bull. Chem. Soc. Jpn.2001;74:1273-1278.

54. Ghazy S E, Kabil, M A Determination of trace copper in natural waters after selective separation by flotation. Bull. Chem. Soc. Jpn 1994;67:474-478.

55. Ghazy S E, Rakha T H, El-Kady E M, El-Asmy A A, Use of some hydrazine derivatives for the separation of mercury(II) from aqueous solutions by flotation technique. Indian J. Chem. Technol 2000;7:178-182.

56. Pol'kin S I, Berger G S, Revazashavili I B, Shchepkina M M. Phase diagram and collector properties of oleic acid with changing pH. Izv. Vyssh. Ucheb. Zaved. Tsvet. Met.1968;11:6-11.

57. Ramachandra R S. Surface Chemistry of Froth Flotation, Vol. 2 Reagents and Mechanisms, 2nd ed., Kluer Academic / Plenum Puplishers, New York, 1982. 